\title{
Sistem Informasi Rekam Medis Di Klinik Gigi Rumah Sakit Paru dr. Ario Wirawan Salatiga
}

\author{
Heribertus Ary Setyadi ${ }^{1}$, Doddy Satrya Perbawa ${ }^{2}$ \\ ${ }^{1,2}$ Universitas Bina Sarana Informatika Kampus Surakarta \\ e-mail: ${ }^{1}$ heribertus.hbs@bsi.ac.id, ${ }^{2}$ doddy.dwp@bsi.ac.id

\begin{tabular}{ccc}
\hline Diterima & Direvisi & Disetujui \\
$01-11-2021$ & $03-11-2021$ & $07-12-2021$ \\
\hline
\end{tabular}

\begin{abstract}
Abstrak - Teknologi bereperan baik sebagai media interaksi sosial Saat ini pelayanan di klinik gigi Rumah Sakit Paru dr. Ario Wirawan (RSPAW) masih menggunakan cara konvensional atau offline. Proses pendaftaran pasien dapat dilakukan dengan datang ke klinik untuk mengambil nomor antrian. Untuk pasien baru wajib mengisi form pasien baru. Setelah itu pasien akan diperiksa oleh dokter, jika pasien yang sudah pernah periksa maka dokter akan melihat blangko yang berisi rekam medis pasien. Selesai proses pengerjaan dokter menulis terapi yang sudah diberikan di blangko rekam medis pasien. Tahap analisis yang dilakukan adalah menganalisis permasalahan sistem yang sedang berjalan dan analisis kebutuhan sistem yang dikembangkan. Langkah perancangan dari sistem yang dikembangkan dalam penelitian ini adalah membuat bagan alir sistem yang dikembangkan, diagram arus data, desain input, desain output dan desain basis data. Sistem dibuat menggunakan visual basic dan Ms.Acces. Sistem yang dikembangkan dalam penelitian ini meliputi pengolahan data pasien, data diagnosa, data tindakan data obat, data dokter. Fasilitas pemeriksaan pasien yang ada dalam sistem antara lain riwayat penyakit dan namnesa, diagnosa pasien, tindakan pemerisaan pasien, obat yang diberikan dan poto ronsen. Sistem dapat menghasilkan daftar pasien, daftar dokter, daftar obat, daftar diagnosa, daftar tindakan, laporan rekam medis, laporan penjualan obat dan laporan pemasukan.
\end{abstract}

\section{Kata Kunci : Rekam Medis, Klinik Gigi, Visual Basic}

\begin{abstract}
Abstrak - Currently the service at the dental clinic at the Lung Hospital, dr. Ario Wirawan (RSPAW) still uses conventional or offline methods. The patient registration process can be done by coming to the clinic to take a queue number. New patients are required to fill out a new patient form. After that the patient will be examined by the doctor, if the patient has been examined, the doctor will see a blank containing the patient's medical record. After completing the process, the doctor writes the therapy that has been given on the patient's medical record blank. The analysis phase carried out is analyzing the problems of the current system and analyzing the needs of the system being developed. The design step of the system developed in this research is to make a flow chart of the system developed, data flow diagrams, input design, output design and database design. The system is made using visual basic and Ms. Access. The system developed in this study includes patient data processing, diagnostic data, drug data action data, doctor data. Patient examination facilities that exist in the system include medical history and name, patient diagnosis, patient examination procedures, drugs given and X-ray photos. The system can generate patient lists, doctor lists, drug lists, diagnostic lists, action lists, medical record reports, drug sales reports and income reports.
\end{abstract}

\section{Keywords : Medical Records, Dental Clinic, Visual Basic}

\section{PENDAHULUAN}

Klinik Gigi berdasarkan peraturan menteri kesehatan RI nomor 920/Menkes/Per/XII/1986 adalah sarana layanan kesehatan gigi dan mulut yang diberikan kepada masyarakat dan penyelenggaraannya dilaksanakan oleh pemerintah dan swasta (Zaroh, et al., 2017) Klinik gigi adalah lembaga kesehatan yang bergerak dalam penyediaan pelayanan kesehatan masalah gigi. Pencatatan data riwayat kesehatan pasien merupakan hal penting dalam dunia medis dan dikenal dengan istilah data rekam medis. Selama pasien melakukan pemeriksaan atau menjalani perawatan medis oleh dokter atau suatu instansi medis maka status kesehatan pasien tesebut masih tercatat sebagai data rekam medis pasien. Data rekam medis pasien tersebut dapat digunakan sebagai acuan dalam pemeriksaan kesehatan selanjutnya sekaligus bukti tercatat mengenai diagnosa penyakit pasien dan pelayanan medis yang diperoleh pasien (Ira dan Diki, 2017).

Rekam medis adalah keterangan baik yang tertulis maupun yang terekam tentang identitas, anamnesis, penentuan fisik, laboratorium, diagnosa segala pelayanan dan tindakan medik yang diberikan kepada pasien dan pengobatan baik yang di rawat 
inap, rawat jalan, maupun yang mendapat pelayanan gawat darurat (Raihan, 2021)

Dalam menjalankan tugas di pelayanan kesehatan perlu didukung adanya rekam medis yang lengkap. Menurut PERMENKES Nomor 269/MENKES/PER/III/2008 yang dimaksud rekam medis adalah berkas berisi catatan dan dokumen antara lain identitas pasien, hasil pemeriksaan, pengobatan serta tindakan dan pelayanan lain yang telah diberikan kepada pasien. Setiap dokter termasuk dokter gigi dalam menjalankan praktik kedokteran wajib membuat rekam medis yang lengkap setelah pasien menerima pelayanan. Yang mana rekam medis merupakan salah satu informasi penting yang harus diisi secara tepat dan harus terjaga kerahasiannya. (Aprilliyani et al., 2018)

Dalam penelitian terdahulu oleh Prawirodirjo dkk membahas sistem rekam medis rawat jalan di klinik gigi Bright Smiles Bali. Proses yang dikerjakan dalam penelitian ini antara lain pendaftaran pasien, pencatatan rekam medis pasien rawat jalan, pencatatan data dokter, pencarian kode ICD $9 \mathrm{CM}$, pencarian kode ICD 10. serta menghasilkan berbagai laporan dan informasi rekam medis pasien yang dibutuhkan (Prawirodirjo et al., 2018). Sistem yang dibuat belum menghasilkan laporan rekam medis pasien dalam bentuk tampilan maupun print out.

Penelitian yang dilakukan oleh Zaroh dkk dengan judul Rancang Bangun Sistem Informasi Layanan Rekam Medis Praktik Dokter Gigi Bersama Di Tabing membuat sistem berbasis WEB untuk memberikan data penunjang rekam medis. Dalam sistem yang dibuat selain mengelola rekam medis juga mengelola data obat atau resep yang diberikan serta transaksi pembayaran (Zaroh, et al., 2017). Laporan rekam medis yang dihasilkan masih dalam bentuk yang sederhana, data yang ditampikan belum sesuai dengan kebutuhan dokter.

Saat ini pelayanan di klinik gigi RSPAW masih menggunakan cara konvensional atau offline. proses pendaftaran pasien dapat dilakukan dengan datang ke klinik untuk mengambil nomor antrian. Untuk pasien baru wajib mengisi form pasien baru. Setelah itu pasien akan diperiksa oleh dokter, jika pasien yang sudah pernah periksa maka dokter akan melihat blangko yang berisi rekam medis pasien. Setelah itu proses pengerjaan, selesai proses pengerjaan dokter menulis terapi yang sudah diberikan di blangko rekam medis pasien. Setelah itu terapi beserta tarifnya ditulis dokter di kertas. Kertas tadi dibawa pasien ke kasir untuk proses pembayaran. Seluruh kegiatan tersebut menghabiskan cukup banyak waktu untuk memproses seluruh pasien serta menyebabkan media penyimpanan yang semakin lama semakin penuh. Dokter kesulitan dalam memonitor rekam medis pasien secara cepat.

Pentingnya informasi bagi suatu pelayanan kesehatan termasuk klinik, karena informasi yang cepat, tepat dan akurat akan memberikan hasil pelayanan yang baik bagi pasien dan memberikan kepuasan kepada pasien. Penggunaan komputer akan membuat efektif dan efisien dalam melakukan pengolahan data. Pengolahan data yang dilakukan secara konvensinal butuh waktu yang lama menimbulkan ketidakvalidan data dan kerahasiaan data tidak dapat terjaga dengan baik. Klinik gigi sangat membutuhkan suatu sistem informasi sebagai sarana promosi, pendaftaran dan perjanjian yang dapat menunjang dan memberikan pelayanan yang memuaskan bagi para pasien. (Dewi \& Inge, 2019).

Berdasarkan permasalahan yang ada dan perkembangan teknologi informasi serta untuk meningkatkan pelayanan kepada pasien seperti yang telah diuraikan, penulis tertarik untuk mengangkat tema tersebut menjadi penelitian. Tujuan penelitian ini adalah mewujudkan suatu sistem yang dapat membantu dalam melayani pasien di klinik gigi rumah sakit paru dr. Ario Wirawan Salatiga. Yang dikerjakan dalam penelitian ini khususnya untuk pembuatan sistem adalah pengelolaan data pasien, pengelolaan rekam medis, menyimpan hasil ronsen dan transaksi pembayaran. Sistem yang dibuat juga dapat menghasilkan nota pembayaran dan laporan yang dibutuhkan.

\section{METODE PENELITIAN}

Penelitian dilakukan di klinik gigi Rumah Sakit Paru dr. Ario Wirawan (RSPAW) Salatiga. Metode yang digunakan pada penelitian ini adalah metode deskriptif analisis yaitu dengan cara mengumpulkan data, menganalisa data, membuat suatu pemecahan masalah, dan kemudian disusun untuk menarik kesimpulan mengenai masalah tesebut. Ada dua teknik dalam metedologi penelitian yaitu teknik pengumpulan data dan teknik pengembangan sistem (Ramadani\& Heltiani, 2019).

\section{Metode Pengumpulan Data}

a. Observasi

Pada metode ini, penulis melakukan observasi langsung di Klinik Gigi RSPAW Salatiga guna memperoleh data sistem rekam medis saat ini yang akan dikelola menjadi sebuah sistem. Penulis mengamati peristiwa, kejadian, proses, dan sejenisnya disertai dengan daftar yang perlu diobservasi. Pada kegiatan ini juga diperoleh formulir, format data dan kode atau nomor juga bentuk laporan yang ada.

b. Wawancara

Dalam metode ini, peneliti melakukan wawancara secara langsung dengan kepala Klinik gigi RSPAW Salatiga untuk mendapatkan informasi tentang sistem rekam medis. Bagaimana proses pendaftaran pasien sampai dengan pencatatan rekam medis pasien yang telah diperiksa.

c. Studi Literatur

Studi literatur adalah pengumpulan data 
melalui buku-buku, dokumen, jurnal atau hasil penelitan terdahuu yang erat kaitannya dengan topik yang dibahas dalam penelitian. (Junaidi \& Zaman, 2019)

\section{Metode Pengembangan Sistem}

Tahapan untuk pengembangan sistem dalam tugas akhir ini menggunakan metode Incremental yang sudah dikembangkan dari model waterfall, karena metode Incremental ini terdiri dari tahaptahap yang memberikan kemudahan, jika pada satu tahap tidak sesuai atau mengalami kesalahan maka dapat kembali ketahap sebelumnya.

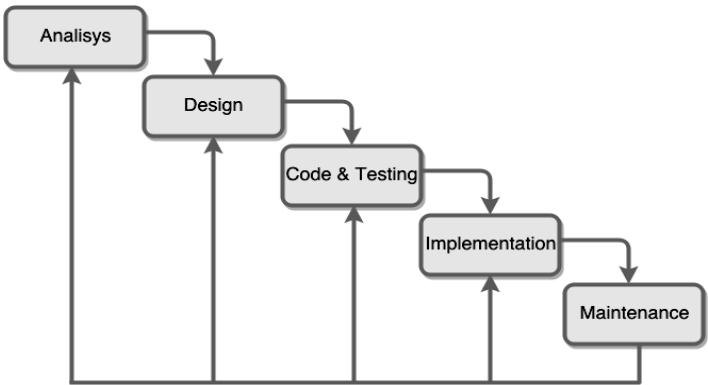

Sumber : Muslihudin dan Oktafianto, 2016 Gambar 1. Model WaterFall

3. Alur Penelitian

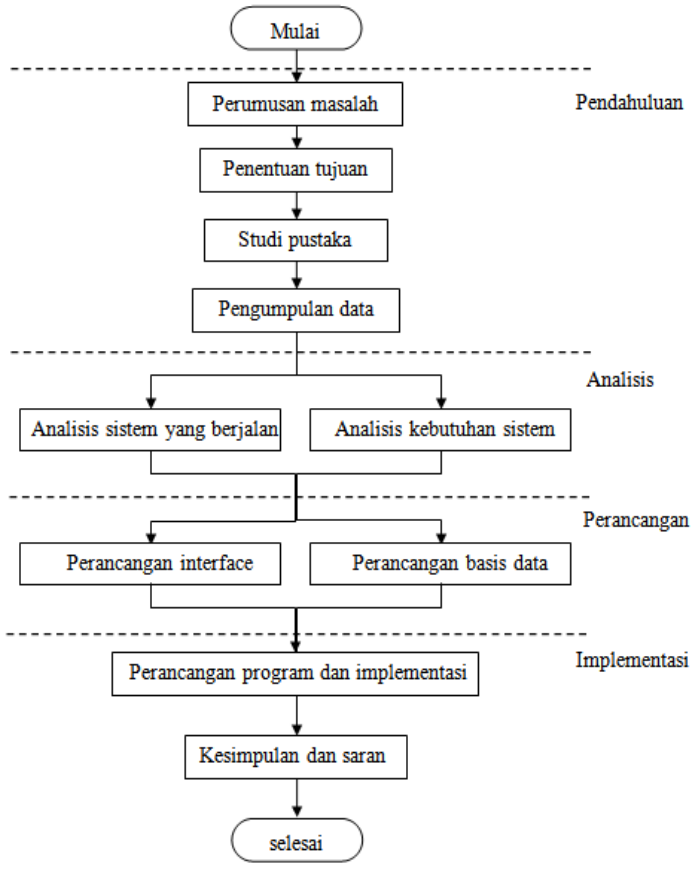

Sumber : Penelitian Penulis

Gambar 2. Alur Penelitian

\section{HASIL DAN PEMBAHASAN}

1. Analisa Kebutuhan Sistem

Sistem yang diusulkan dapat menyimpan data dalam bentuk file (paperless) dan backup data, integrasi data menjadi tidak terhambat dikarenakan data dapat saling terhubungan antar unit-unit yang terkait. Sistem ini juga dapat membantu petugas front office untuk menyimpan data pasien. Pencatatan rekam medis pasien pada sistem sehingga pencarian data rekam medis menjadi mudah saat dokter atau perawat membutuhkan informasi rekam medis pasien dan data rekam medis dapat diakses oleh perawat dan dokter secara lengkap. Data rekam medis dibutuhkan dokter sebagai pertimbangan dalam menentukan penanganan dan terapi untuk pasien. Hasil triage dan anamnese, perawat juga dapat melakukan input data penanganan yang dilakukan kepada pasien, terapi dan data hasil pemeriksaan unit penunjang sehingga dapat diakses apabila dibutuhkan.

\section{Diagram Arus Data (DAD) Level 0}

Dalam DAD level 0 terdapat tiga proses utama yaitu mengolah data master, memeriksa pasien dan mencetak laporan. Dalam sistem yang dikembangkan membutuhkan sepuluh tabel dalam database. Ada lima tabel yang berfungsi sebagai data master yaitu pasien, dokter, tindakan, diagnosa dan obat. Lima tabel lagi digunakan untuk menyimpan transaksi antara lain tinpas (tindakan), diapas (diagnosa), opas (obat), riwayat dan ronpas (ronsen). Semua tabel tersebut akan direlasikan untuk mengelola transaksi dan membuat laporan. DAD level 0 dari sistem yang dikembangkan dapat dilihat di gambar 3 .

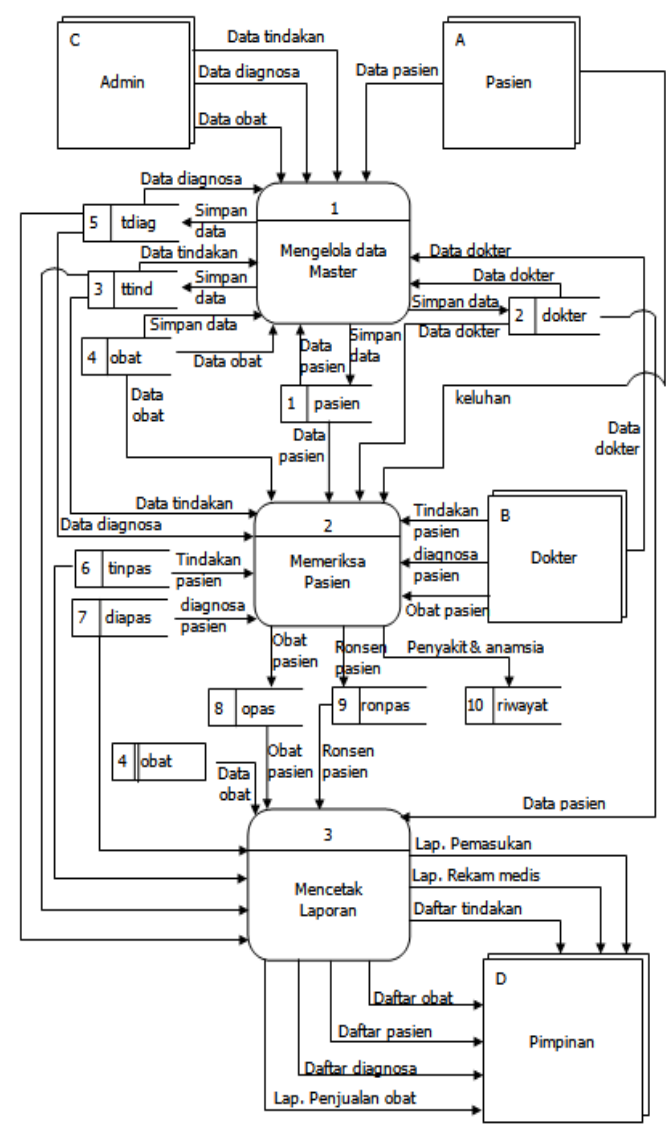

Sumber: Hasil Penelitian

Gambar 3. DAD Level 0 Sistem Rekam Medis Klinik Gigi 


\section{DAD Level 1 Proses Pengolahan Data Master}

Terdapat lima proses yaitu mengelola data tindakan, data diagnosa, data obat, data dokter dan data pasien. Kelima proses ini akan menjadi dasar dalam proses perawatan pasien dan mencetak laporan. Terdapat lima tabel yang dibutuhkan dalam proses mengolah data master yang juga digunakan untuk relasi dalam mengelola transaksi yang ada maupun membuat laporan yang dibutuhkan.



Sumber: Hasil Penelitian

Gambar 4. DAD Level 1 Proses Mengolah Data Master

4. DAD Level 1 Proses Pemeriksaan Pasien Terdapat lima proses dan melibatkan sepuluh atau semua tabel yang ada dalam proses pemeriksaan pasien.

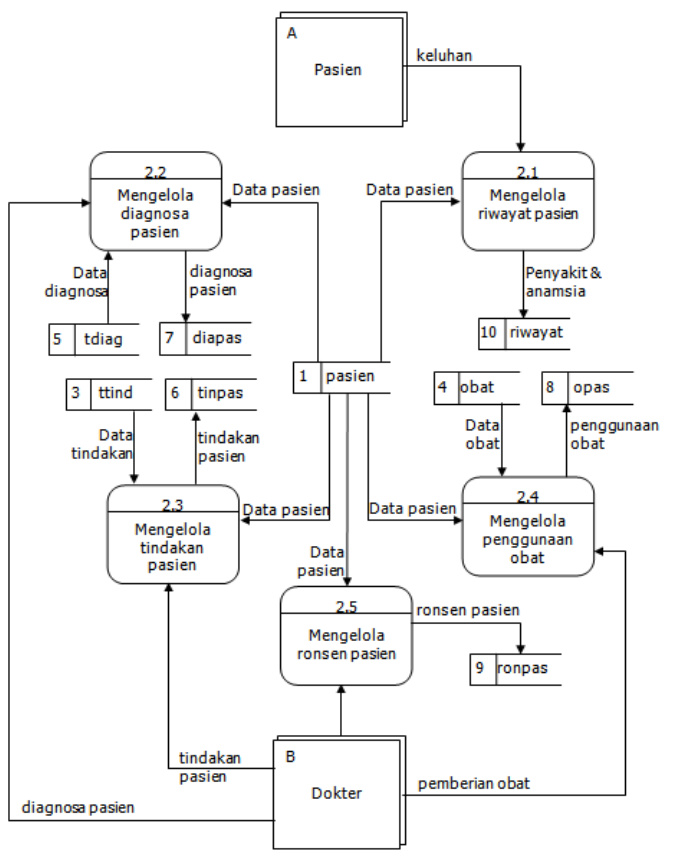

Sumber: Hasil Penelitian

Gambar 5. DAD Level 1 Proses Pemeriksaan Pasien

\section{Relasi Antar Tabel}

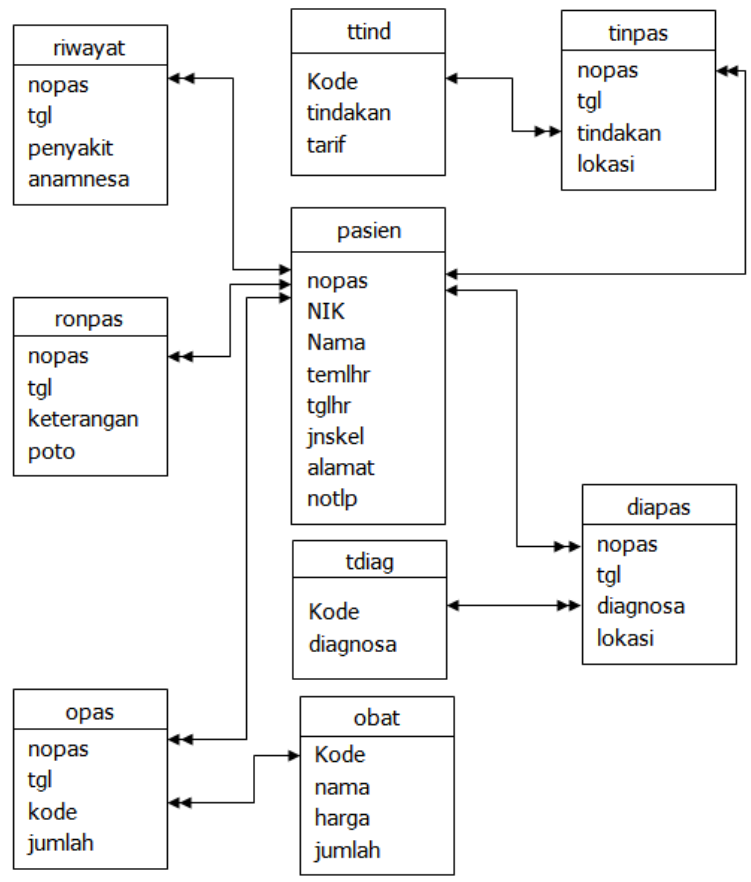

Sumber: Hasil Penelitian

Gambar 6. Relasi Antar Tabel

\section{Implementasi Sistem}

Implementasi sistem atau aplikasi yang telah dibuat dibutuhkan beberapa perangkat lunak. Sistem informasi atau aplikasi dibuat menggunakan bahasa pemrograman desktop. Untuk implementasi dibutuhkan aplikasi yang sudah dipasang di komputer antara lain windows minimal windows XP, Visual Basic dan Ms.Access.

Tampilan sistem yang dibuat terintegrasi dalam suatu menu utama yang sederhana. Terdapat empat pilihan dalam menu utama, di dalam setiap pilihan terdapat beberapa form yang dijadikan dalam satu tampilan sehingga operator tidak perlu banyak membuka dan menutup form.

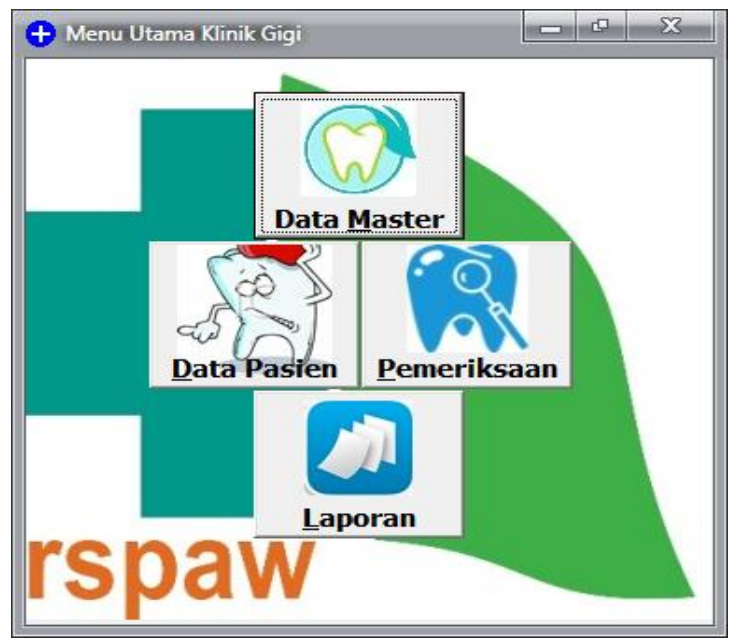

Sumber: Hasil Penelitian

Gambar 7. Tampilan Menu Utama 
Ketika memilih menu pemeriksaan maka pengguna harus mengisi nomor pendaftaran pasien. Pengguna juga dapat memilih nomor pendaftaran dengan cara menekan tombol “..." maka akan tampil seperti gambar 8. Pengguna dapat melakukan pencarian data psien yang sudah mendaftar kemudia menekan tombol enter atau klik dua kali di data pada tabel maka data pasien yang dimaksud sudah tampil di form. Setelah memasukkan atau memilih nomor pendaftaran maka akan muncul nomor pasien, nama, tanggal lahir dan usia.

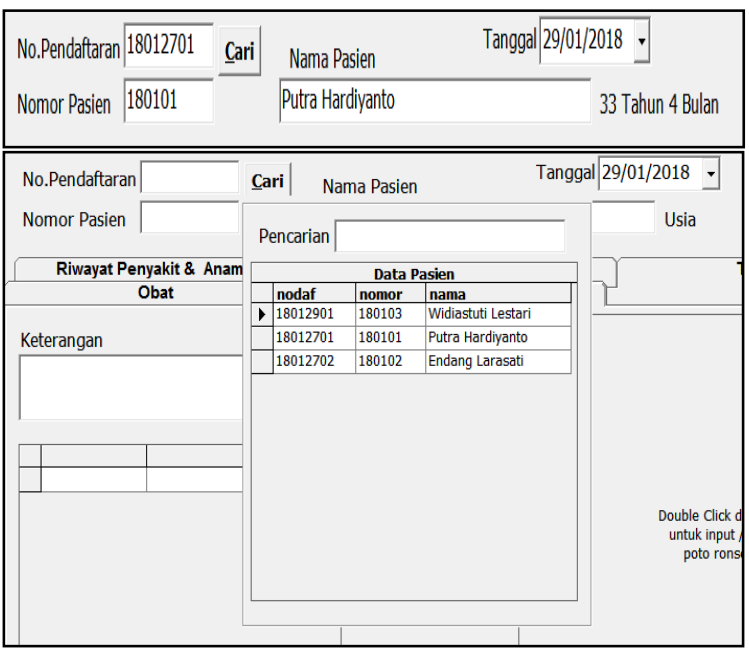

Sumber: Hasil Penelitian

Gambar 8. Tampilan Awal Pemeriksaan Pasien

Proses diagnosa pasien pertama kali yang dilakukan dokter adalah memasukkan kode diagnosa. Dokter juga dapat memilih data diagnosa dari tabel sebelah kanan dengan klik dua kali pada data yang dimaksud. Setelah data diagnosa tampil kemudian memasukkan lokasi gigi yang diperiksa, lalu menekan tombol simpan. Selain data diagnosa, sistem juga menyimpan data pasien dan tanggal diagnosa yang didapat dari tampilan awal pemeriksaan.

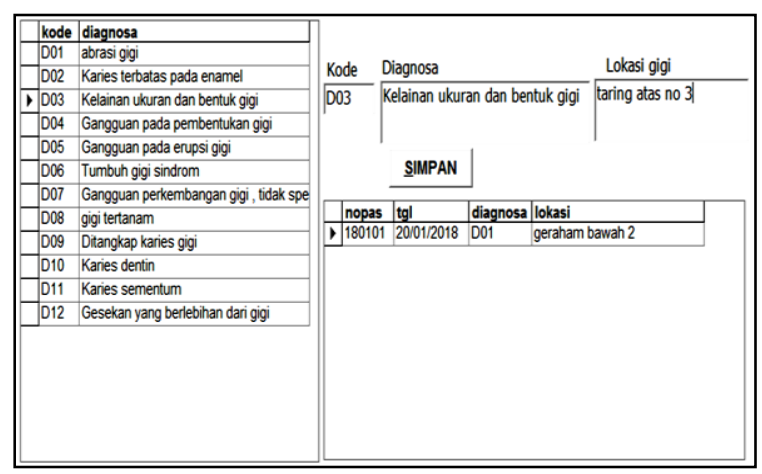

Sumber: Hasil Penelitian

Gambar 9. Tampilan Diagnosa Pasien

Cara mengoperasikan pengolahan tindakan pasien sama dengan diagnosa pasien.

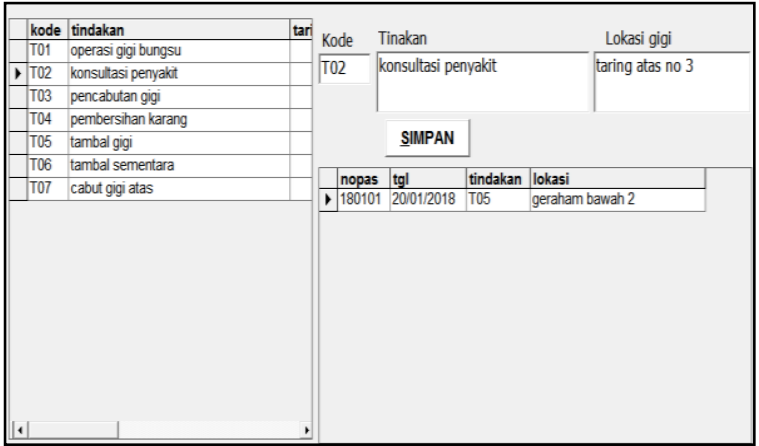

Sumber: Hasil Penelitian

Gambar 10. Tampilan Tindakan Kepada Pasien

Mengoperasikan pengolahan pemberian obat tidak jauh beda dengan tindakan dan diagnosa pasien. Setelah memasukkan atau memilih kode obat lalu memasukkan jumlah obat yang akan diberikan maka total biaya obat muncul otomatis.



Sumber: Hasil Penelitian

Gambar 11. Tampilan Pengolahan Pemberian Obat

Proses ronsen ini dikerjakan jika memang ada ronsen pasien. Setelah memasukkan keterangan lalu memilih poto ronsen dengan klik dua kali pada kotak poto kemudian memilih poto yang sudah disimpan maka poto ronsen yang dimaksud akan tampil.

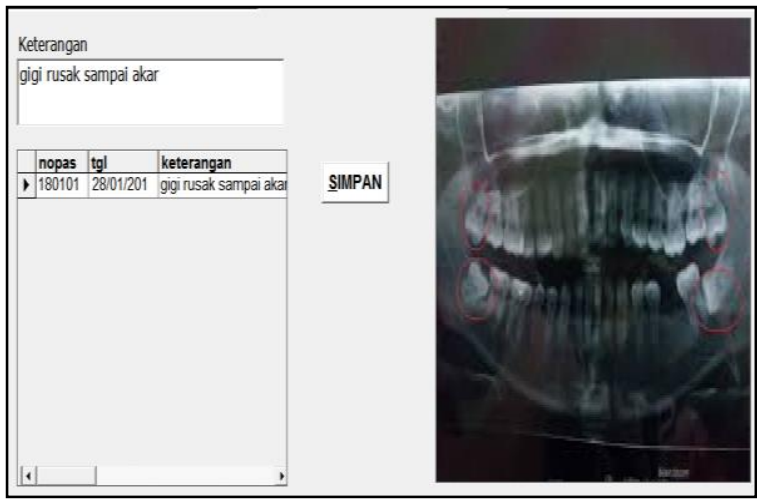

Sumber: Hasil Penelitian

Gambar 12. Tampilan Pengolahan Ronsen Pasien

Form rekam medis menampilkan semua tentang pemeriksaan dari seorang pasien mulai dari riwayat penyaki sampai tindakan yang pernah dilakukan. 
Setelah memasukkan nomor pendaftaran maka pada menutab rekam medis akan otomatis menampilkan histori pemeriksaan.

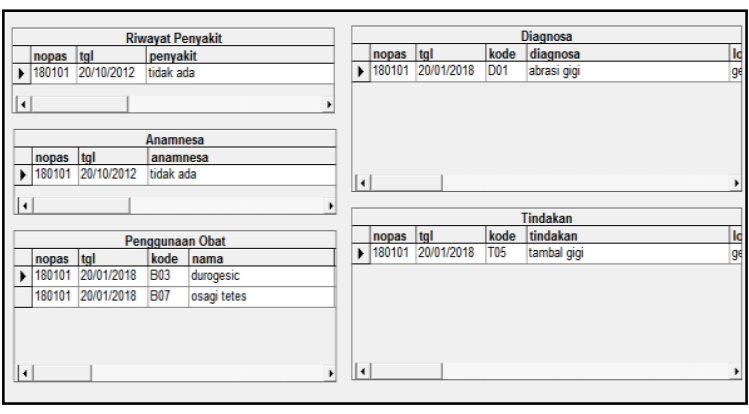

Sumber: Hasil Penelitian

Gambar 13. Tampilan Rekam Medis Pasien

Gambar 14 merupakan tampilan untuk memilih daftar atau laporan yang akan dicetak. Setelah memilih lalu pengguna menekan tombol cetak maka daftar atau laporan yang dimaksud akan tampil.

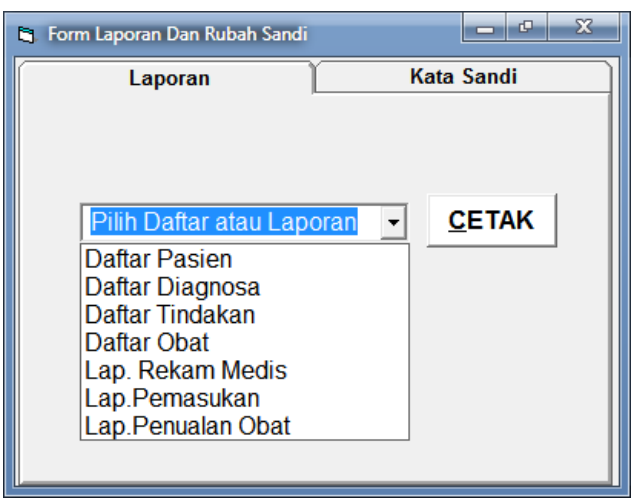

Sumber: Hasil Penelitian

Gambar 14. Tampilan Pengolahan Laporan

\section{KESIMPULAN}

a. Hasil tahap analisis sistem yang berjalan adalah sistem yang digunakan masih menggunakan cara konvensional dan sebagian menggunakan komputer dalam pengolahan data rekam medis di klinik gigi. Langkah berikutnya menganalisis kelemahan sistem dengan menggunakan metode PIECES dan analisis kebutuhan sistem yang dikembangkan.

b. Langkah-langkah perancangan dari sistem yang dikembangkan dalam Tugas Akhir ini adalah membuat bagan alir sistem yang dikembangkan, diagram arus data, desain input, desain output dan desain basis data

c. Sistem atau aplikasi dibuat dengan menggunakan bahasa pemrograman visual basic dan Ms.Access sebagai databasenya.

d. Sistem yang dikembangkan dalam Tugas Akhir ini meliputi pengolahan data pasien, data diagnosa, data tindakan data obat, data dokter. Fasilitas pemeriksaan pasien yang ada dalam sistem antara lain riwayat penyakit dan namnesa, diagnosa pasien, tindakan pemerisaan pasien, obat yang diberikan dan poto ronsen.

e. Sistem dapat menghasilkan daftar pasien, daftar dokter, daftar obat, daftar diagnosa, daftar tindakan, laporan rekam medis, laporan penjualan obat dan laporan pemasukan

f. Untuk pengembangan selanjutnya perlu dibuat jaringan lokal agar dapat terintegrasi antara pendaftaran dan dokter serta bagian yang berkaitan .

g. Perlu dikembangkan aplikasi berbasis web.

\section{REFERENSI}

Aprilli; Inayati, Aini; Fauzi, Feddi Dea. (2018). Desain Database Sistem Informasi Rekam Medis Berbasis Microsoft Access Di Klinik Dokter Gigi. Jurnal Hospita Science 2(2) 1-8 http://e-journal.stikesmuhbojonegoro.ac.id/ index.php/JHS/article/download/110/62/

Dzulhajmi, Isnaniah \& Kusumadiarti, Rini Suwartika. (2018). Perancangan Sistem Informasi Rekam Medis Rawat Jalan Menggunakan Pendekatan Berorientasi Objek Di Rumah Sakit Khusus Gigi Dan Mulut (Rskgm) Kota Bandung. Jurnal Petik, 4(1), 71-78. https://journal.institutpendidikan.ac.id/index. php/petik/article/view/8/pdf

Junaidi, A., \& Zaman, K. (2019). Rancang Bangun Sistem Informasi Retensi Rekam Medis dengan Metode Imaging Berbasis Web. INTECOMS: Journal of Information Technology and Computer Science, 2(1), 3339.

https://doi.org/https://doi.org/10.31539/inteco ms.v2i1.753

Lestari, Dewi; Handriani, Inge. (2019). Analisa Dan Perancangan Aplikasi Sistem Pelayanan Klinik Gigi (Studi Kasus: Dental Echo Clinic). JSAI 2(1) 127-134. http://jurnal.umb.ac.id/ index.php/JSAI/article/view/158/pdf

Muslihudin, Muhamad \& Oktafianto. (2016). Analisis dan Perancangan Sistem Informasi Menggunakan Model Terstruktur dan UML. Andi Offset. Yogyakarta.

Prawiradirjo, Dewa Made Andika Dwi \& Kartiko, Bambang Hadi. Perancangan Sistem Informasi Rekam Medis Elektronik Rawat Jalan Berbasis Web Di Klinik Gigi Bright Smiles Bali. Jurnal Teknologi Informasi dan Komputer, $\quad 4(1)$ 31-41. https://jurnal.undhirabali.ac.id/index.php/juti k/article/view/392

Raihan, Faza Muhammad, 2021, Perancangan Sistem Informasi Rekam Medis Pada Klinik Saffira Sentra Medika Batam, Snati, 1(1), 4756. 
https://journal.uii.ac.id/jurnalsnati/article/vie w/20066/11409.

Ramadani, Niska., \& Heltiani, Nofri. (2019). Perancangan Sistem Informasi Rekam Medis Puskesmas Sukamerindu. Jurna Edik Informatika, 6(1), 55-64. https://doi.org/10.22202/ei.2019.v6i1.3694

Sari, Ira Puspita \& Arisandi, Diki. (2017). Sistem Informasi Manajemen Klinik Gigi Berbasis Client Server (Studi Kasus Poliklinik Gigi RSJ Tampan, Pekanbaru). RABIT 2(1). http://jurnal.univrab.ac.id/index.php/rabit/arti cle/view/151/100

Zaroh, AA., Irfan, D., \& Tasrif, E. (2017), Rancang Bangun Sistem Informasi Layanan Rekam Medis Praktik Dokter Gigi Bersama Di Tabing. Votenika : Jurnal Vokasional Teknik Elektronika \& Informatika, 5(2), 24-29. https://doi.org/10.24036/voteteknika.v5i2.847 2 